\title{
Characteristics of Paperbrick with Inequitable Substitution of Cement
}

\author{
M.S. Britto Jeyakumar, Y. Kamala Raju
}

\begin{abstract}
Paper bricks are key construction materials for buildings in general and for low cost housing in particular. To keep up with sustainable development movements and increasing competitive pressure in the industry, building materials of the upcoming have to be of lesser weight, more force capable and lower cost. The use of recycled materials is also critical for longterm sustainability.

The intention of this paper is to develop lightweight paper brick from waste paper with lowest amount. The paper was hydrating and spin to obtain paper mash slurry after mixing with cement, and cast to shape. Compressive strength and water absorption were found. The results showed that investigational bricks are upper compressive force, water absorption when compared to those of existing masonry blocks. Quick cost estimation indicated that bricks could be made at a lower cost than those available in the market. It is fulfilled that paper bricks as of waste paper possess smart property and high-quality strengths. Sustainable and rate issues are also addressed. The result show the arrangement of paper dissipate and cement provides improved results for produce economical latest bricks.
\end{abstract}

Keywords : Sustainability, paper waste, paper-pulp slurry, water absorption.

\section{INTRODUCTION}

Since a big call for has been positioned on constructing material industry particularly inside the ultimate decade, because of the growing population which causes continual storage of building substances, the civil engineer has been challenged to transform industrial wastes to useful building and construction materials

Then with the help of graph, a comparison between Compressive strength, Water absorption and Efflorescence of ordinary bricks and paper bricks was determined. Before manufacturing the bricks, different properties of materials (cement and paper) were verified. After that, bricks were made and sun dried and then with the help of compressive strength machine (CTM), their compressive strength was calculated. The purpose of this study was to use waste paper to produce light weight masonry bricks. At make we have covered a type of paper brick before, but it was used simply as fire starter

Rahul Ralegaonkar and Sachinmandavgane of the Visveavaraya National Institute of Technology in India have come up with a process to make paper bricks designated for creation instead of destruction. It started when they visited a paper recycling plant in 2009. They learned that $15 \%$ of the material that went through the plant was piled up into an un sighting sludge and sent to a landfill.

Raleganokar and Mandavgane decided to take some of that sludge back to their lab and play around with it along with students over the summer. They are found when the bricks were made at $90 \%$ recycled paper mill waste and $10 \%$ cement. The slurry is mechanically mixed pressed into moulds, and left in the sun to dry. The bricks are half the cost of conventional ones, much lighter and could be a suitable to the Indian construction economy, which is $30 \%$ deficit in brick masonry (Including rice husk, fly ash,cotton waste etc.)

\section{LITERATURE REVIEW}

Rahul Ralegaonkar and Sachin mandavgane of the Visveavaraya National Institute of Technology in India have come up with a process to make paper bricks designated for creation instead of destruction. It started when they visited a paper recycling plant in 2009. they learned that $15 \%$ of the material that went through the plant was piled up into an un sighting sludge and sent to a landfill.

\section{Physical properties of Paper}

At Smithers Pira we are expert in testing the physical properties of paper to specific standard requirements. We specialize in creating bespoke test programmes based on your requirements, such as investigating product failure or weakness. We can also work with you to develop a custom test method, should it be needed.You can browse each section listed on the right to see our full range of tests. We are always happy to talk to you about the suitability of particular tests, so please make contact with the Smithers Pira expert shown if you have questions about the test itself or the support you need for your particular project or issue.

As standard, all of our tests are performed in a controlled laboratory environment. However, we have the capability to combine any of the above testing services at a set temperature or after exposure to freezing temperatures or high humidity.

\section{Physical properties of Cement}

Cement is the most important material for Civil Engineering Construction of Buildings, Dames, Bridges, Channels, Culverts, etc. It must be understood that cement is a chemical and reacts when mixed with water. Cement particles develop a type of growth on its surface until it link up with the growth from the neighbouring cement particles. It is this linking which results in progressive stiffening, hardening and strength development. 


\section{Characteristics Of Paperbrick With Inequitable Substitution Of Cement}

The chemical reaction continues in the presence of free water, moisture or humidity present within the mass or outside. The mix becomes harden and stronger with age. This strength development is significant in the first month but it does not continue at a much slower rate for many years is called " HYDRATION " of cement and is accompanied by generation of heat which is called "Heat of hydration"

\section{RAW MATERIALS}

In the experimental work raw materials used as follows :

\section{Cement:}

In this have a look at, cement which is used is an normal port land cement. It acts as an awesome binder with paper sludge to supply paper brick. It hardens quickly when mixed with paper sludge and water.

\section{Paper:}

Paper used in this research was taken as waste news paper and in this project.

\section{Sample preparation:}

In this study, three different mix ratios were used as shown table 1 the water and waste paper mixes were kept constant and the proportion of cement was varied. For each ratio, ten samples were prepared.

The standard brick mould size 190*90*90 mm

\section{EXPERIMENTAL WORK \& RESULTS}

Methods used to prepare the Paper brick:

The desecrate paper was soaking in water for day.

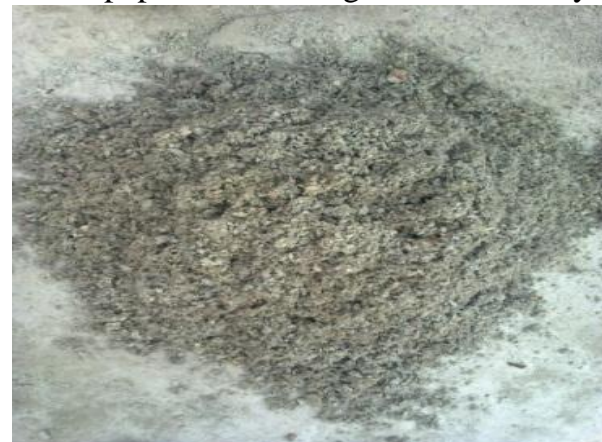

Fig. 1 In wet condition and in dry condition

Pour the cement into the paper pulp and blend it thoroughly

Now upload the water and mix it at a uniform shade

Pore the mixed proportion into the mould

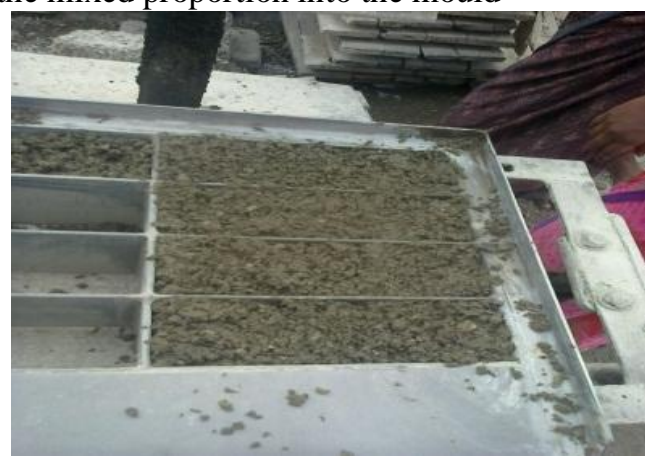

Fig. 2 shake the blend to take out the air with the facilitate of Vibrator apparatus

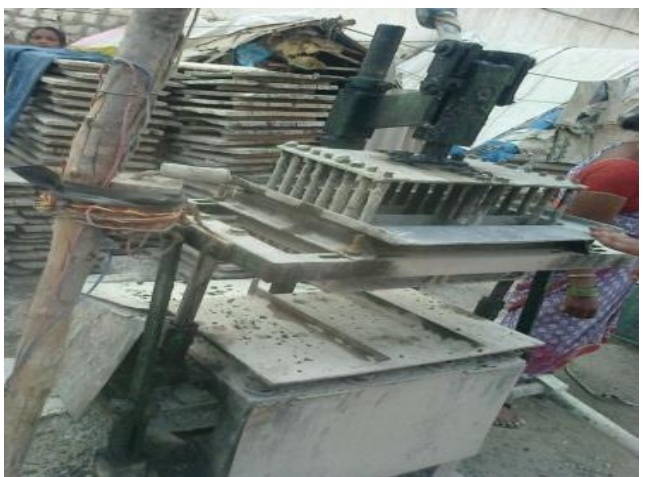

Fig. 3Remove the forms (moulds)

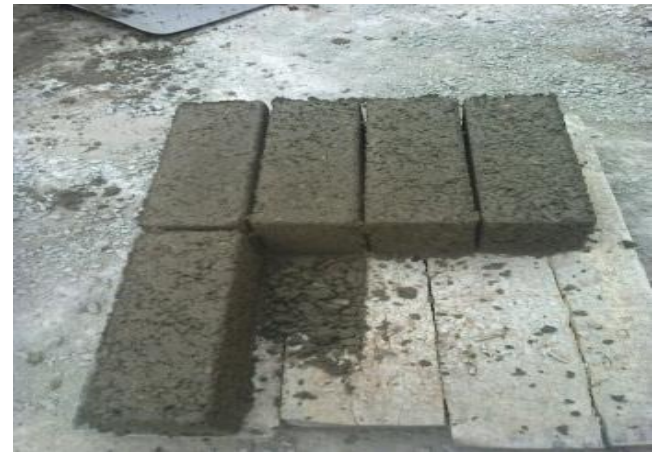

Fig. 3Let the Bricks dry for at least one week.

Compressive force of bricks : ( I S 3495 : 1992 )

A wall or column carrying a compressive load behaves like any other strut, and its load bearing capacity depends on the compressive strength of the materials, the cross sectional area and the geometrical properties as expressed by the slenderness ratio.

1) Compressive testing machine (CTM)

2) Scale for measuring dimension of brick

Compressive Strength $=\frac{\text { Maximum load at failure }}{\text { Area of the in } \mathrm{mm}}$

The normal Compressive strength of bricks (IS 3495: 1992) is 35Mpa.

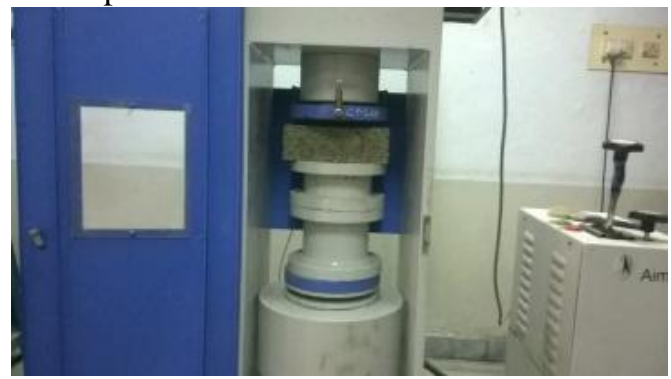

Fig. 4 While doing the Compressive strength in Laboratory:

Formulae for Water absorption:

Water absorption $=\frac{\mathrm{M} 2-\mathrm{M} 1}{\mathrm{M} 1} * 100$

The average of result shall be reported.

while hardened, the standard water absorption shall not be extra $20 \%$ by weight.

1) NIL: - When there is not perceptible deposit of efflorescence.

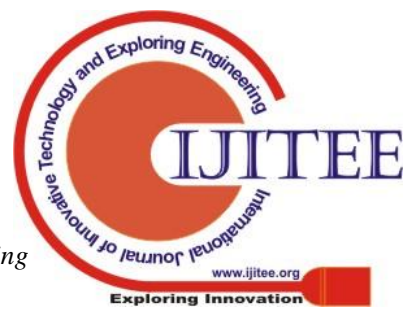


2) Slight: - Not more than $10 \%$ area of the brick covered with a thin deposit of salt.

3) Moderate: - Covering up to $50 \%$ area of the brick.

4) Heavy: - Covering 50\% or more area but un accompanied by powdering or flaking of the brick surface.

5) Serious:- When there is a heavy deposit of salts accompanied by powdering and flaking of the exposed surfaces.

While doing Efflorescence in laboratory:

\section{Caluclations For Compressive Strength}

Compressive Strength $=\frac{\text { Maximum load at failure }}{\text { Area of the in } \mathrm{mm}}$

Size of the brick $220 * 80 * 70 \mathrm{~mm}$

$>$ For $85 \%$ of newspaper crush, $15 \%$ of cement:

$$
\text { Load at failure }=60 \mathrm{KN}
$$

Compressive strength $=\left(60 * 10^{3}\right) / 220 * 80$

$$
=3.41 \mathrm{Mpa}
$$

$>$ For $80 \%$ of newspaper crush, $20 \%$ of cement : Load at failure $=55 \mathrm{KN}$

Compressive strength $=\left(55^{*} 10^{3}\right) / 220 * 80$

$$
=3.13 \mathrm{Mpa}
$$

$>$ For $75 \%$ of newspaper crush, $25 \%$ of cement :

Load at failure $=65 \mathrm{KN}$

Compressive strength $=\left(65 * 10^{3}\right) / 220 * 80$

$$
=3.70 \mathrm{Mpa}
$$

Table I: Compressive Strength

\begin{tabular}{|c|c|c|}
\hline Specimen & $\begin{array}{c}\text { \% Of Cement } \\
\text { Add }\end{array}$ & $\begin{array}{c}\text { Compressive } \\
\text { Strength in } \\
\text { (Mpa) }\end{array}$ \\
\hline S1 & $15 \%$ & 3.41 \\
\hline S2 & $20 \%$ & 3.13 \\
\hline S3 & $25 \%$ & 3.70 \\
\hline
\end{tabular}

Calculations For Water Absorption

Formulae for calculating Water absorption $=\frac{\mathrm{M} 2-\mathrm{M} 1}{\mathrm{M} 1} * 100$ M1 = The weight of the brick is before pour into the water

M2 =The weight of the brick after taken from the water

For $85 \%$ of newspaper crush, $15 \%$ of cement

$$
\mathrm{M} 1=810 \mathrm{gm} \quad \mathrm{M} 2=1100 \mathrm{gm}
$$

Water absorption $=\frac{1100-810}{810} * 100=35.8 \%$

$>\quad$ For $80 \%$ newspaper crush, $20 \%$ cement

$$
\mathrm{M} 1=760 \mathrm{gm} \quad \mathrm{M} 2=1010 \mathrm{gm}
$$

Water absorption $=\frac{1010-760}{760} * 100=32.8 \%$

For $75 \%$ Paper pulp, $25 \%$ cement

$$
\mathrm{M} 1=900 \quad \mathrm{M} 2=1160
$$

Water absorption $=\frac{1160-900}{900} * 100=28.8 \%$

Table- II: Water Absorption Results

\begin{tabular}{|c|c|c|}
\hline Specimen & $\begin{array}{c}\text { \% Of } \\
\text { Cement } \\
\text { Add }\end{array}$ & $\begin{array}{c}\text { Water } \\
\text { Absorption } \\
\text { in ( \%) }\end{array}$ \\
\hline S1 & $15 \%$ & 35.8 \\
\hline S2 & $20 \%$ & 32.8 \\
\hline S3 & $25 \%$ & 28.8 \\
\hline
\end{tabular}

Calculations for Efflorescence

For $85 \%$ of newspaper crush, $15 \%$ of cement

For more than $10 \%$ of area of the brick covered with a thin deposit a thin deposit of salt.

Efflorescence is Slight

For $80 \%$ newspaper crush, $20 \%$ cement

For surplus $10 \%$ of region of the brick covered with a thin deposit a thin deposit of salt.

So, It has Slight Efflorescence

For $75 \%$ Paper pulp, $25 \%$ cement

For surplus $10 \%$ of region of the brick covered with a thin deposit a thin deposit of salt.

So, It has Slight Efflorescence

Table III. Efflorescene results:

\begin{tabular}{|c|c|c|}
\hline case & $\begin{array}{c}\text { \% Cement } \\
\text { include }\end{array}$ & Efflorescence \\
\hline S1 & $15 \%$ & Slight \\
\hline S2 & $20 \%$ & Slight \\
\hline S3 & $25 \%$ & Slight \\
\hline
\end{tabular}

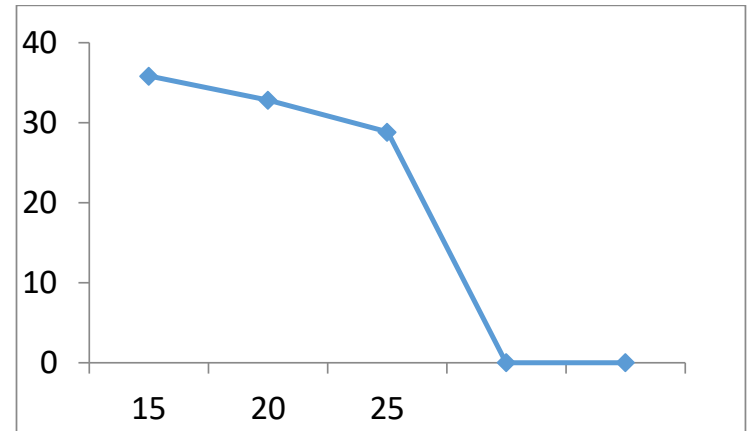

Fig5. Cement in \% vs Water absorption in \%

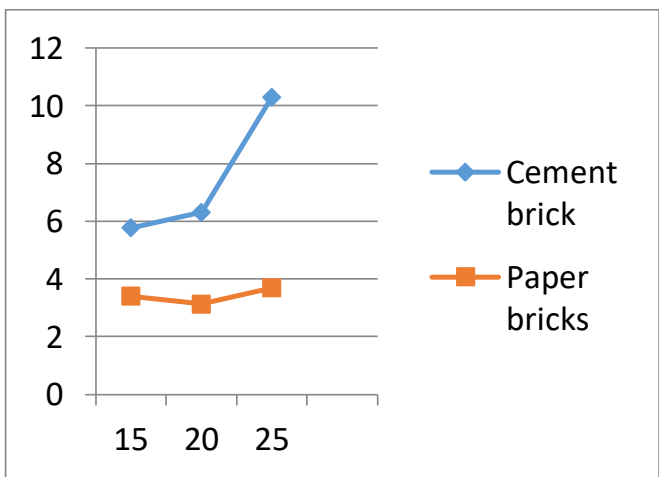

Fig 6. Comparison of Compressive strength between Cement brick and Paper brick

Cement in \% vs Compressive Strength in Mpa 
Table IV: Test Results

\begin{tabular}{|c|c|c|}
\hline Case & $\begin{array}{c}\text { \% Of Paper } \\
\text { Sludge }\end{array}$ & $\begin{array}{c}\text { \% Of } \\
\text { Cement }\end{array}$ \\
\hline C 1 & $85 \%$ & $15 \%$ \\
\hline C 2 & $80 \%$ & $20 \%$ \\
\hline C 3 & $75 \%$ & $25 \%$ \\
\hline
\end{tabular}

The $190 * 90 * 90 \mathrm{~mm}$ size bricks were prepared and used as test specimens to determine the compressive strength and water absorption respectively. The specimens were prepared with various percentages of cement and paper sludge.

Table V: Compressive Strength opted :

\begin{tabular}{|c|c|c|}
\hline Case & $\begin{array}{c}\text { \% Of Cement } \\
\text { Add }\end{array}$ & $\begin{array}{c}\text { Compressive } \\
\text { Strength in (Mpa) }\end{array}$ \\
\hline C 1 & $15 \%$ & 3.41 \\
\hline C 2 & $20 \%$ & 3.13 \\
\hline C 3 & $25 \%$ & 3.70 \\
\hline
\end{tabular}

Table VI: Water Absorption grades

\begin{tabular}{|c|c|c|}
\hline Case & $\begin{array}{c}\text { \% Of } \\
\text { Cement } \\
\text { Included }\end{array}$ & $\begin{array}{c}\text { Water Absorption in ( } \\
\text { \%) }\end{array}$ \\
\hline C 1 & $15 \%$ & 35.80 \\
\hline C 2 & $20 \%$ & 32.80 \\
\hline C 3 & $25 \%$ & 28.80 \\
\hline
\end{tabular}

Table VII: Efflorescence opted

\begin{tabular}{|c|c|c|}
\hline $\begin{array}{c}\text { Specime } \\
\text { n }\end{array}$ & $\begin{array}{c}\text { \% Of Cement } \\
\text { Included }\end{array}$ & Efflorescence \\
\hline C 1 & $15 \%$ & Slight \\
\hline C 2 & $20 \%$ & Slight \\
\hline C 3 & $25 \%$ & Slight \\
\hline
\end{tabular}

\section{CONCLUSIONS}

Based on the experimental investigation the subsequent effects were determined.

The superior $(\%)$ Of cement substitute in paper brick and compressive energy of the bricks have studied.

Paper bricks extra low-priced the time required to prepare bricks much less in comparison to normal bricks

\section{REFERENCES}

1. Recent trends in civil engineering www.stmjournals.com (v-4, issue2) 2014

2. www.civilengineeringportal.com

3. http://www.livingpaper.com

4. http://www.familyonbikes.org/educate/lessons/paperhous es.htm

5. www.ascelibrary.com

6. www.brickjournal.com
AUTHORS PROFILE

Mr. M. S. Britto Jeyakumar, Assistant Professor of Civil Engineering, completed his Master of Engineering (Structural Engineering) from Sathyabama University, Chennai. He has over 1.5 years of academic experience in Gokaraju Rangaraju Institute of Engineering and Technology (GRIET) and 7.5 years of Rajas Engineering College, Tamilnadu. He had 9.5 years of industrial experience at varies industrial organizations. He had earned Bachelors of Engineering (Civil Engineering) Madurai kamaraj university, Tamilnadu. His research interests include Concrete Technology and Design of Concrete Structures, in which he has 3 publications, in various conferences. He is currently Class coordinator, Department of Civil Engineering at Gokaraju Rangaraju Institute of Engineering and Technology (GRIET). He is also a Life Member of ISTE and IASTER.

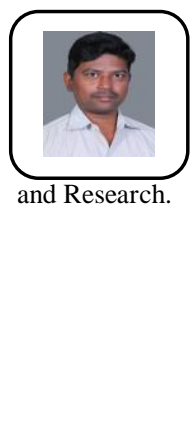

Er.Y. Kamala Raju, Assistant Professor of Civil Engineering, He recseived his B. E in Civil Engineering from Osmania University in 2007, and M. Tech in Structural Engineering from JNTUK in 2011. Over 10 years of professional experience in Industry, Academic 